\title{
CROSS-CULTURAL BEHAVIOUR IN THE BOARDROOM
}

KATERINA REZNICKOVA 
"Nothing in business circles brings such a rush of clichés to the head as leadership... an area in which there is no absolute, no guaranteed model... so it turns out to be not only vital but also fun to talk about what makes a leader."

- Sir Peter Baker

According to Mullins (2005, p. 281) there are a number of ways to look at leadership and its interpretation. In general, leadership is mostly understood in terms of "getting others to follow" or as "the use of authority in decision-making to get people to do things willingly" (Mullins, 2005). Leadership can also be practiced as part of one's position, or through knowledge and/or pursuing new ideas, for example, in the case of Steve Jobs and his famous remark that many times people simply do not know what they want until it is shown to them (BusinessWeek, 1998). Despite the number of different leadership theories on "what makes a good leader" during the beginning of the 20th century, it was not until the advances in technology, especially the developments in telecommunications allowing us to do business on a global and more interconnected scale, that triggered researchers to look at the impact culture might have on leadership itself with its attached impact on human behaviour. The focus of this paper is on how leadership is conceptualised across cultures and the challenges of leadership in a cross-cultural context. To do so, the concept of culture and different leadership theories will be defined with practical examples of how leadership is influenced by our culture and how this could give us a better understanding of human behaviour in the workplace.

Throughout our history, geographical, ethnical, and political boundaries have been built, creating differences among various groups of people, which we now know as different cultures. Similarly to leadership, culture has numerous meanings. According to Browaeys and Price (2011, p. 9) culture is an essential part of all human societies, where each society defines its own norms and the ways in which they are realised. At an organisational level, Edgar Schein (1992) defines culture simply as a reflection of shared assumptions emerged from problem solving, which eventually becomes a model for new members as the right way to think in connection to such problems (Schein, 1992). Taking into account Armstrong's (1990) interpretation of leadership, where being a leader means meeting certain objectives or achieving tasks through more than one person, it is not a surprise that cross-cultural theories have generally underlined a strong connection between culture and leadership styles (House et al., 2002, p. 3).

A number of researchers, including Renate Mayntz and Norbert Elias, believe that cultural traditions, values, ideologies and norms are bound to differentiate more than structural factors between societies (Lammers and Hickson, 1979, p. 10) and that the historical developments influence the degree of cooperation, morale, and commitment to an organisation (House et al., 2002). Hofstede's well-known framework $(1980,2001)$ of the five cultural dimensions (namely: individualism-collectivism, uncertainty avoidance, power distance, masculinity-felinity, and long-short term orientation ${ }^{1}$ ), analyses countries according to work-related values. Hofstede's theory was later partially used together with the work of Trompenaars and Hampden-Turner (1997) in the project GLOBE in a more recent effort to demonstrate the impact culture has on diverse perception of leadership across the world (Dickson et al., 2012). The ultimate aim of the GLOBE project is to help leaders better understand the human behaviour in the workplace and therefore choose a relevant style of leadership.

This is of course under the assumption that there are appropriate leadership theories to choose from, which according to Peter Blunt and Marrick L. Jones (1996) might be tricky, considering many of these theories have been developed in the last fifty years. One could say though that there has not been adequate time to test their application in practice and so their scientific credentials remain ambiguous.

1 Originally, Hofstede identified four cultural dimensions; a fifth dimension (short-long term orientation) was added in his work in 2001 
The extent to which leadership is conceptualised differently across cultures can be seen in number of examples. Trait theory, one of the early studies of leadership focusing on the personal traits of qualities that one has to have in order to be perceived as an effective leader (Morden, 2004, p.203), indicates that being more formal and acting with self-confidence to assert leader's influence over others belongs among those traits needed to be successful (Browaeys and Price, 2011, p. 448). This trait, however, might be unacceptable in certain countries like Japan, where having a good relationship determines the role of a person in most situations (Adachi, 2010).

In the same fashion, Collins and Porras' study (1996) points out that the success of transformational leadership, which concept is based on leader's ability to promote innovation and new technologies through changing the organisation's mission, strategy, and culture (Morden, 2004, p. 229) is mostly demonstrated in American companies and such an approach has not been fully proven to be successful in companies based in the United Kingdom. A similar conclusion with regard to transformational leadership has been also reached in the study carried out in Botswana by Jones et al. (1995), in which followers perceived those who provide clear direction and targets as effective leaders, rather than those who concentrate on long-term strategy, communicating a corporate vision, and securing broad commitments (Jones et al., 1995).

Last but not least, an example of pointing out the challenges of leadership theories in cross-cultural context is situational leadership. Blanchard's et al. (1985) model, describing four different kinds of situational leadership styles: (i) directing, (ii) coaching, (iii) supporting, and (iv) delegating, suggests that the leader's behaviour must be relevant to the situation, and it is up to the leader to decide which style to adopt. Nonetheless, as cited by Van Zandth (1970), in Japan for instance (and in other Asian countries) concept of "face" can come into play. Meaning that the leader might decide on a certain course, not based on the situation but in order to save face, and therefore the concept of adjusting the leadership based on the given situation becomes irrelevant.

Even though the examples outlined earlier indicate that some leadership theories do not seem to work so well in particular cultures, it does not mean that they would not work anywhere else. For instance, transformational leadership appears to work very well in the US market, as demonstrated by the case of Jack Welch, former CEO of the US General Electric (GE) Corporation who transformed GE into an aggressive and profitable international player (Morden, 2004, p. 229) and similarly, transactional leadership works just fine in the cultures with higher hierarchy (i.e. Hofstede's power distance) like in most Asian countries or Russia, where authority is perceived as a right and the hierarchy is naturally accepted.

The extent to which leadership changes due to culture is best observed in connection with cultural preferences, the so-called loosely knit social framework. According to Dickson et al. (2012), a social position of different cultures on Hofstede's dimension of individualism vs. collectivism indicates contrasting leadership perceptions, meaning that highly individualistic cultures (e.g. the United States and the UK) connect organisational success as well as its failure directly with the Chief Executive Officers (CEOs) of companies. When Apple's CEO, Steve Jobs, died, Apple's ability to sustain its market leadership after Jobs' death was a topic of debate (Bedigian, 2011). At the same time, their perception of accountability for failure is nearly zero. Top leaders in more collectivistic cultures (e.g. Japan, China, and other Asian countries) are rarely seen as the main cause behind the organisational accomplishments, yet they are quite often found liable for (sometimes) even non-business related failure. This is best demonstrated by the comparison between the prompt resignation of Tokyo Electric Power's CEO, Masataka Shimizu, taking a full responsibility for the crisis at the Daiichi nuclear plant following the severe earthquake in 2011 (Tabuchi, 2011) and the reluctance of British Petrol CEO, Tony Hayward, to resign or even accept any accountability in connection to the oil spill in the Gulf of Mexico in 2012. 
Understanding the challenges of leadership in cross-cultural context is, however, not the only element to think about. Apart from the need to take the cultural differences into account, there is also the necessity to understand human behaviour within the relevant organisation. That is, as explained by Mullins (2005), because an organisation itself is made up of individual members with different needs and expectations. When these are not met, it can lead to frustration and eventually result in conflict, which can be demonstrated by the following practical situation based on the author's personal experience.

Back in 2010, the author worked for an Internet security provider, founded in the Czech Republic, headquartered in the Netherlands and with operations across the world. The company appointed a new Chief Operating Office (COO) to round up a strong leadership team and to take the company to the next level (i.e. bring the company public). Coming from the United States was noticeably reflected on his uniformed leadership practices, one of his first big tasks was to restructure the company and to effectively dismiss around $10 \%$ of the workforce. While affected employees from the US subsidiary took the news as part of the job market reality, German employees ended up suing the company and for the people in the Czech Republic the new $\mathrm{COO}$ became the most "hated man" in the company resulting in resignations by several key employees as a form of protest and arguably lower performance by others. A behavioural reaction that nobody expected, affected operations substantially for the next several months.

In the COO's own view, which he later discussed with the rest of the executive management team, he believed that he did everything right. Or at least how he would do it in the United States, where it had been done a number of times and worked out just fine. Meaning, to acknowledge everyone's hard work and at the same time explain that in order for a company to move to the next level, things have to change quickly, and therefore some people might need to go. Only later he admitted that while he did expect people to get upset, he did not foresee, nor did he understand the reaction of employees, particular the ones in Europe and the broad implications that would eventually cost him his job. This example illustrates the challenges of leadership theories in cross-cultural context and to supports the argument that leadership is conceptualised differently across cultures, but it does yet not give us a good understanding of human behaviour in the workplace.

There is a close link between cross-cultural theories and leadership theories, which theory is supported by a number of researchers, including Hofstede, Mayntz, and Elias, because cultural values, norms, and ideologies have a fundamental impact on leaders as well as followers' behaviour. House et al. (2002) points out that in addition to the values and beliefs, it is also the historical developments that influence the degree of cooperation, morale, and commitment to the organisation. This all together is one of the reasons why leadership is conceptualised differently across cultures. The story about the $\mathrm{COO}$ clearly demonstrates the practical application of opposite applicability of transformational leadership among American British organisations.

Furthermore, several leadership theories such as trait theory, transformation or situational theory were summarised from which we concluded that none of them translates to the globalised setting in which organisations operate. For example, adjusting the leader's approach based on the situation he/she happens to be in could possibly work in European counties quite opposite to Asian countries, where even unfitting decisions can be made in order to save face. There is also a different understanding of taking the responsibility as was shown on the case of BP's CEO Tony Hayward and his Japanese counterpart Masataka Shimizu. For this reason, we cannot really consider leadership theories as truly global concepts.

Finally, despite the guidance leadership theories might provide, and even if we take the element of cultural diversity into account, they still do not explain how people in the organisations will react (behave), and therefore they are not particularly helpful in understanding peoples' behaviour in an organisational setting. This is because they are being discussed from an egocentric point of view and do not take into the account the human element of the equation between leader and follower. 


\section{REFERENCES}

Adachi, Y. (2010) 'Business Negotiations Between the American and the Japanese', Global Business Languages, (2) 4.

Bedigian, L. (2011) 'Can Apple Survive Without Steve Jobs?' Forbes. 25 August [Online]. Available at: http://www.forbes. com/sites/benzingainsights/2011/08/25/can-apple-survive-without-steve-jobs/ (Accessed: 3 December 2014).

Armstrong, M. (1990) How to be an even better manager. London: Kogan Page.

Blanchard, K.H., Zigarmi, D. and Zigarmi, P. (1985) Leadership and the One Minute Manager: Increasing effectiveness through situational leadership. New York: William Morrow.

Blunt, P. and Jones, M.L. (1997) 'Exploring the limits of Western leadership theory in East Asia and Africa', Personnel Review, 26 (1/2), pp. 6-23.

Browaeys, M.J. and Price, R. (2011) Understanding Cross-Cultural Management. 2nd edn. Harlow: Pearson Education Ltd., pp. 9, 448.

Collins, J.C. and Porras, J.I (1996) Built To Last. London: Century Business.

Dickson, M.W., Castano, N., Magomaeva, A. and Hartog, D. (2012) 'Conceptualizing leadership across cultures', Journal of World Business, 47, pp. 483-492.

Hofstede, G. (1980) Culture's consequences: International differences in work-related values. Beverly Hills, CA: Sage.

Hofstede, G. (2001) Culture's consequences: Comparing values, behaviors, institutions, and organizations across nations. 2nd edn. Newbury Park, CA: Sage.

House, R., Javidan, M., Hanges, P. and Dorfman, P. (2002) 'Understanding cultures and implicit leadership theories across the globe: an introduction to project GLOBE', Journal of World Business, 37, pp. 3-10.

Jones, M.L. and Blunt, P. (in press). 'Management education in Africa', in Warner, M. International Encyclopedia of Business and Management. London: Routledge

Lammers, C.J. and Hickson, D.J. (1979) Organizations alike and unlike: International and inter-institutional studies in the sociology of organizations. London: Routledge and Kegan Paul.

Morden, T. (2004) Principles of Management. 2nd edn. Aldershot: Ashgate Publishing Limited.

Mullins, L.J. (2005) Management and organizational behavior. 7th edn. Harlow: Pearson Education Ltd.

Schein, E.H. (1992) Organizational culture and leadership. 2nd edn. San Francisco: Jossey-Bass.

Tabuchi, H. (2011). 'Head of Japanese utility steps down after nuclear crisis'. The New York Times. 20 June [Online]. Available at: http://www.nytimes.com/2011/05/21/business/global/21iht-tepco21.html?pagewanted=all

(Accessed: 10 December 2014).

The Business Week (1998) 'Steve Jobs on Apple's resurgence: "not a one-man show"' [Online]. Available at: http:/ / www.businessweek.com/bwdaily/dnflash/may1998/nf80512d.htm (Accessed: 3 December 2014).

Trompenaars, F. and Hampden-Turner, C. (1997) Riding the waves of culture: Understanding cultural diversity in business. 2nd edn. London: Nicholas-Brealey.

Van Zandt, H.F. (1970) 'How to Negotiate in Japan', Harvard Business Review, 11(70613), [Online]. Available at: http:// hbr.org/1970/11/how-to-negotiate-in-japan/ar/1 (Accessed: 10 May 2014). 